\title{
TRADITIONAL THEORY ABOUT THE ORIGIN OF THE LATIN IMPERFECT ${ }^{*}$
}

Despite numerous attempts to throw light upon the origin of the Latin imperfect, this question has not been adequately explained yet. The present article tries to summarise the traditional theory about the formation of this Latin tense and the most resounding hypotheses about its origin.

Keywords: Latin, imperfect.

Introduction

The imperfect tense expresses a continuous past action which is unfinished, as the name itself indicates - im-perfectum. This characteristic accounts for its three uses:

a) pure, durative imperfect

b) iterative imperfect and

c) imperfect de conatu. These uses are best preserved in Greek but were also used in Latin, where the forms of the old imperfect disappeared. In Proto-Germanic, the IE imperfect, the aorist and the perfect continue partly in the old perfect and partly in its counterpart, the preterite, while, in Proto-Slavonic, the old imperfect for nonmomentary actions was replaced by forms ending in *ahz. ${ }^{1}$ In Italic languages, the functions of the IE imperfect passed on into the compounds with *bhuam.

\section{Towards the formation of the Latin imperfect}

Latin imperfect, formed with the suffix $-b a$-, which is a constituent part of all Latin verbs in the indicative mood except for the verb esse, functionally corresponds to the IE imperfect. It continues the imperfective aspect of the IE imperfect, which expresses a past action in progress (as unfinished), however, its use is much narrower than in Greek, for example. It is formed from the present stem of the verb by adding the suffix - $b a$ - (in the $1^{\text {st }}$ and $2^{\text {nd }}$ conjugations) or -eba- (in the $3^{\text {rd }}$ and $4^{\text {th }}$ conjugations); the endings are the same as for the present, except in the $1^{\text {st }} \mathrm{sg}$., where the ending is $-m$, which is an IE secondary ending.

\footnotetext{
* The article is an abridged version of a part of the author's MA thesis on The Imperfect in Cicero's Texts, which deals with the development of the Imperfect tense from Indoeuropean to Latin as well as with its use from the beginnings of Latin literature to the period of late Latin, with particular regard to Cicero's texts. The thesis was presented on March 242000 before a panel of examiners consisting of the following members: Prof. Erika Mihevc Gabrovec, Prof. Matjaž Babič, and Dr. Marko Marinčič.
}

1 Cf. Brugmann 1922: 573-574, Krahe 1972: 125-126, Szemerényi 19904: 323. 
The main part and basic characteristic of the Latin imperfect is the suffix -bam, which most probably originates from a form of the auxiliary verb "to be". Most grammarians agree ${ }^{2}$ that the suffix $-b a m$ derives from an older form ${ }^{*} b h u-\bar{a}-m$, which in turn derives from the IE root *bheuH-, the meaning of which was "to grow" (hence "to originate", "to become", "to exist", "to be", "to retain", "to live"). In Proto-Italic, the form * $b h u-\bar{a}-m$ developed into *-fäm (the proof of this can be found in the Oscan form fufans $^{3}$ ); what has been left of it are $-b$ - and $-f$ - in the imperfect of Italic languages. The Latin imperfect containing $-b a$ - is not formally connected with the IE imperfect, but is a Proto-Italic new form and is, together with $b$-future, an ItalicCeltic particularity. In grammar books and treatises, the imperfect and the future are always discussed together as $b$-tenses. The proof that this is a particularity of Italic can be found in other Italic languages, like the aforementioned Oscan form of the $3^{\text {rd }} \mathrm{pl}$. fufans, which functionally, but not formally, corresponds to the Latin erant; its Latin counterpart would be ${ }^{*} f u b a n t$. Nevertheless, this is not the only proof for $b$ - (or $f$-) tenses in Italic languages. Besides the Oscan imperfect fufans, we can also find the future form carefo in Faliscan, which corresponds to the Latin form carebo and pafo or pipafo (= Lat. bibam); both forms have been preserved in inscription on goblets. ${ }^{4}$

The $-b-/-f^{5}$ future can also be found in Celtic, but not in Oscan (which has $f$-perfect) or Umbrian. So, $b$ - or $f$-future can be found in Celtic languages, Latin and Faliscan, while the imperfect can be found in Latin, Oscan and Umbrian. This fact indicates an entirely Italic formation.

\section{The time of the formation of the Latin imperfect}

The origin of the Latin imperfect can only be loosely defined. Due to the Oscan form fufans (= Lat. erant) "they were" (the only preserved form of this imperfect in Oscan) formed from * bhu-bhuant, it is presumed that this periphrastic formation was already present in Proto-Italic. However, one needs to be careful when discussing the imperfect as a Proto-Italic formation. Namely, the stem of the aforementioned Oscan imperfect is questionable, as there only exists one example, and also because the formation of the imperfect from the root ${ }^{*} b h u$ - with the suffix ${ }^{*} b h u-\bar{a}$ - derived from the same root, is not highly likely; Latin also did not form the corresponding

2 LHS 19775: 579, Meillet-Vendryes 1948: 292-293, Matasovič 1997: 220-221, Ernout-Meltzer 19202, 3 , Ernout-Meillet $1974^{3}$, Palmer 1990.

3 For other experimental explanations of the form fufans see LHS 19775: 579-580.

4 Cf. LHS 19775: 578, Walde-Hofmann 1938/19543: 103, 167.

5 Cf. Sommerfelt 1907, Thurneysen 1909: 372, Leumann 1924, Hermann 1948. 
${ }^{*}$ fubant, but favoured erant ${ }^{6}$ instead, although, by its formation, it falls out of the frame of other $b$-imperfect tenses. ${ }^{7}$

The question of the chronological origin of the future and the imperfect still remains open. As Old Irish forms the $f-/ b$-future from derived verbs, a conclusion was made long ago about a common origin of the future form in Irish, Latin and Faliscan. This could have happened in the area to the north of the Alps before the Latin peoples settled in Italy, in the times when the Irish and Latin predecessors were neighbours. The connection between the Latin and Old Irish future forms was one of the most important points on which the theory about the existence of a protoLatin-Irish community was based (Walde 1917). As the Oscans and Umbrians formed the future with the suffix $-s$-, and not the suffix $-b$-, it can be assumed that, in the times of the formation of the future forms, they were not yet neighbours to the Latin peoples; on their arrival to the Italian Peninsula, when they settled near the Latin, they already had an existing future form. The future is therefore older than the imperfect; the latter was only formed in Italy from where it penetrated into Oscan. The origin of the future form dates back into the times when Celtic, Latin and Faliscan were still closely connected, while the origin of the imperfect dates back into the times of closer connection between Latin, Oscan and Umbrian (Pohl 1986: 208; Walde 1917). Leumann believes that the imperfect is older than the future because it appears in all Latin verbs (with the exception of esse) and can also be found in Celtic. The -be/o- future is more recent since, in Latin, it cannot be found in inherited thematic primary verbs (most of which belong to the $3^{\text {rd }}$ and $4^{\text {th }}$ conjugations) which used the old $\bar{e}$-future. At the same time, he advocates the necessary distinction between the imperfect and the future, as both are unequally divided not only by languages, but also within one language into paradigms and verb classes. (Leumann 1924: 60-75, LHS 19775: 579).

\section{Traditional theory about the origin of the Latin imperfect}

Traditional theory explaining the origin of $b$-tenses is "Kompositionstheorie" (composition theory). According to this theory, the auxiliary verb "bheuH- "to be" is added to the pure verb stem or the nominal form. When forming the future of the $1^{\text {st }}, 2^{\text {nd }}$ and partly $4^{\text {th }}$ conjugations, we add the morpheme -be/o- to the last syllable of the present stem and conjugate it like we do the present indicative of verbs in the

6 The suffix $-\bar{a}$ - in eram, erāmus undoubtedly originates in the IE proto-language in some aorist formation (Cf: Old Irish. bá "I was" (< $\left.{ }^{\star} b h u \bar{a} m\right)$, Lithuanian. bùvo "he was" (< $\left.\left.b h u \bar{a} t\right)\right)$. However, we cannot prove the aorist with the root "es- in any IE language; hence the uncertainty regarding the origin of the forms eram, eräs ... cf. Safarewicz 1969, 226-228.

7 Cf. also reduplication in the Oscan perfect. fufens "fuerunt" and the Umbrian future ex. fefure; for a more detailed explanation see Planta 1892/1897: 2, 373; 2, 3282; 2, 331; 2, 342, Buck 1904: § 128, 2a, § 193, Brugmann 1897/1916ㄹ: $\mathrm{II}^{2}, 3,508 \S 421,7$ A.2; $\mathrm{II}^{2}, 3,506$, Leumann 1924: 66-68, Hermann 1948, LHS $1977^{5}: 579$. 
$3^{\text {rd }}$ conjugation. With the imperfect, we add the morpheme -ba- to the last syllable of the present stem and conjugate the new form the way we conjugate the present indicative, with the exception of the $1^{\text {st }} \mathrm{sg}$., which has the IE secondary ending $-m$. Examples:

a) future

\begin{tabular}{|c|c|c|c|}
\hline infinitive & present stem & morpheme & future \\
\hline sanāre & sanā- & $-b e / o-$ & sanābo \\
\hline docēre & docēe- & $-b e / o-$ & docēbo \\
\hline len̄̄re & lenī- & $-b e / o^{-}$ & lenībo \\
\hline dăre & $d \check{a}-$ & $-b e / o-$ & $d a ̆ b \bar{o}$ \\
\hline
\end{tabular}

b) imperfect

\begin{tabular}{|c|c|c|c|}
\hline infinitive & present stem & morpheme & imperfect \\
\hline sanāre & $\operatorname{san} \bar{a}-$ & $-b a-$ & sanābam \\
\hline docēere & doce $\overline{-}$ & $-b a-$ & docēbam \\
\hline lenīre & len $\bar{i}-$ & $-b a-$ & lenībam \\
\hline dăre & $d \check{a}-$ & $-b a-$ & dăbam \\
\hline
\end{tabular}

The present stem also appears in esse and ire:

$$
\begin{aligned}
& \text { esse (stem } \left.\left.{ }^{*} e s-\right)>\text { fut. erō (from * }{ }^{*}-\bar{o}\right) \\
& \text { impf. erām (from *es-ā-m) } \\
& \text { ire } \left.\left(\text { stem }^{*} e i \text { ) }\right)>\text { fut. } \bar{i}-b \bar{o} \text { (from }{ }^{*} e i-b \bar{o}\right) \\
& \text { impf. } \bar{\imath} \text {-bam (from *ei-bā-m) }
\end{aligned}
$$

The common feature of all explanations of the Latin imperfect is that they look for the old preterite form of the stem ${ }^{\star} f u$-, from which Latin $f u \bar{l}$ and Old Latin conjunctive fuâm are derived (cf. also of Old Indian $b h \bar{u}$ - and Greek $\varphi$ u- "to form, to become, to be"), in the ending $-b \bar{a}-m$; this was formed from *-bhu- $\bar{a}-m$ and corresponds in its formation to $e r-\bar{a}-m\left(<{ }^{*} e s-\bar{a}-m\right)$, which was derived from the stem *es-. By its origin, the imperfect form is therefore a periphrasis created with the inflected form of the verb "to be".

On the other hand, explanations of the stem part of the imperfect form differ, because the structure of the part of the verb before the suffix remains unknown. Some grammarians see in it a stem incomprehensible to us today; others a flexible form that was still alive in Latin in historic times, but which later underwent such changes that it cannot be recognised anymore. The fusion of two stems was supposed to correspond to the development of the Romance future tense from the ProtoRomance infinitive + *habyo (e.g. *cantáre hábyo > Fr. chanterai, It. cantarò; Sihler 1995: 554-555). The $1^{\text {st }}, 2^{\text {nd }}$ and partly $4^{\text {th }}$ conjugations of dare, $\bar{i} r e$ and esse have the present stem while, in the $3^{\text {rd }}$ and $4^{\text {th }}$ conjugations (colé-bam, lenie-bam, capie-bam), the present stem is somewhat remodelled; namely, cole-e, lenie-, capie- only appear in this form and, therefore, cannot be regarded as established variants of the verb stem; 
between the stem and the morpheme there is $-\bar{e}-$, for which there is still no adequate explanation. Efforts to discover the origin of the stem of the $3^{\text {rd }}$ and $4^{\text {th }}$ conjugations led to several hypotheses.

\section{Attempts to explain the verb stems of the $3^{\text {rd }}$ and $4^{\text {th }}$ conjugations}

The first part of the imperfect, ending in $-\bar{e}$, could have derived from the $3^{\text {rd }}$ conjugation, and probably became equal to the first part of the Slavonic imperfect in $-\bar{e}$ (cf. Lat. vehe-bam = Old Church Slavonic vezè-ach b); it was similar to a case of a nominal formation or a verbal noun. Later on, forms with -iebam in the $3^{\text {rd }}$ and $4^{\text {th }}$ conjugations probably appeared. However, if this first part is a case of a verbal noun ending in $-\bar{e}$, a question arises how the corresponding verbs ending in $-\bar{a},-\bar{e}$ and $-\bar{l}$ in the $1^{\text {st }}, 2^{\text {nd }}$ and partly $4^{\text {th }}$ conjugations were formed. Bopp placed the Latin imperfect side by side with the Slavonic imperfect (Bopp 1833/1849: II ${ }^{2}$ 399ss.). Schmidt (Schmidt 1871), too, directly equated Latin legē- in legé-bam with Slavonic nesē- in nesě-achb. Both authors influenced subsequent research (cf. Brugmann 1897/19162: II $\left.3^{2}, 506\right)$. In this case, we see in legé- either a) a pure verb stem without an inflexional ending, $b$ ) a stem of a verbal noun, or $c$ ) a fossilised case of a verbal noun without the ending - casus indefinitus (Hoffmann 1920/1924). The weak point of this explanation is the assumption that this is a form which cannot be proved to be an independent and living verb form in Latin.

Hermann (Hermann 1951) tried to prove that the first part of the compound is neither a verbal noun nor casus indefinitus, but a pure stem preserved in combination with ${ }^{\star} b h u \bar{a} m$. He explains the long $\bar{e}$ in the first part on an example of primary verbs of the $2^{\text {nd }}$ conjugation (e.g. plè-bam, sile-bam, fide-bam ...), from where it was to spread to derivatives (e.g. albe-bam, florē-bam, noce-bam ...). He rejected the attempt to explain the long $\bar{e}$ with an ad hoc invented participle ending in $-\bar{e} .8$

Sommer's objection that the imperfect, ending in -bam, is an Italic new form that cannot be directly linked to any IE proto-form (Sommer 1914: 140ss.) was rebutted by Güntert (Güntert 1917). According to the latter, the imperfect lege-bam is an adapted form of an older pre-Italic IE verb form: Güntert saw in legē-the stem of the Greek root aorist of the type $\varepsilon^{2} \lambda \dot{\varepsilon} \gamma \eta .{ }^{9}$ He considered the Italic imperfect as a conti-

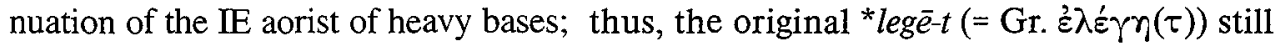
present in Italic was supposed to be replaced by a new formation legê-ba-t . He categorically defended the opinion that ${ }_{-f a} a m$ was originally an independent auxiliary verb directly added to the old aorist stem; he tried to prove with Celtic and Latin compounds (e.g. cale-facio, lique-facio) that adding an auxiliary verb to a verb stem in Italic was nothing unusual. The weakness of his attempt to interpret the imperfect is

8 Cf. Mayer 1956: 120.

9 Cf. Meillet-Vendryes 1948: 292-293. In their opinion, $-\bar{a}$-, which characterises the past tense, has the same role as $-\bar{e}$ - in the Greek aorist of the type é $\mu \alpha \dot{v} \eta \nu$. 
that he was forced to base the formation of the imperfect entirely on the imperfect forms of the $3^{\text {rd }}$ conjugation, as it is only here that the stem in $-\bar{e}$ can be found in pure form; from here it was to spread by analogy to other forms within the conjugation and on to other conjugations. Evidently, Güntert realised the weakness of his attempts himself. Namely, despite advocating lege- as an aorist stem, he soon came up with a surmise that lege- in lege-bam might originally not be a stem after all, but rather a flexible aorist form (Güntert 1917: 18) which could have been formed by the merging of flexible aorist forms $\left({ }^{*} l e g \bar{e}-s,{ }^{*}\right.$ legē-t $\left.\ldots\right)$ with an auxiliary verb ( $\left.{ }^{*}-f \bar{a} s,{ }^{*}-f \bar{a} t\right)$ and a sound change (disappearance of $s$ and $t$ before $f$ ):

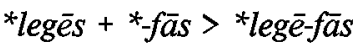

${ }^{*}$ legès $+*$-fāt $>{ }^{*} \operatorname{leg} \bar{e}-f \bar{t} t$

From these forms, ${ }^{*}$ lege- would spread as a stem and then, the following analogy would apply:

$$
\begin{aligned}
& 3^{\text {rd }} \mathrm{sg} .{ }^{\star} \operatorname{leg} \bar{e}-s:{ }^{*} \text { legē-fās } \\
& 1^{\text {st }} \mathrm{pl} .{ }^{*} \text { legē-mus : }{ }^{\star} \text { legēe-fāmus }
\end{aligned}
$$

The deficiency of his explanation was also critically highlighted by Hoffmann (Hoffmann 1920/1924), whose two main doubts were that the Latin imperfect has an unfinished meaning and not an aorist one, and that the merging of two inflected forms into one is a rather unusual phenomenon.

Stowasser and Skutsch took a different approach (Stowasser 1901, Skutsch 1914: 283-292). In $a m \bar{a}-$, legé-, audie--, they looked for a usual verb form preserved in Latin whose meaning would easily explain its connection with -bam. In imperfect forms they saw formations composed of a participle and an auxiliary verb. The result was supposed to be the following:

$\begin{array}{lllll}\text { amā-bam } & < & * \text { *amans-fām } & < & \text { *amants bhūām } \\ \text { legē-bam } & < & \text { *legens-fām } & < & \text { *legents bhūām } \\ \text { audiē-bam } & < & \text { *audiens-fām } & < & \text { *audients bhūām }\end{array}$

This theory was widely approved by classical philologists, yet it left many questions unanswered. The first problem is that, in Old Latin, common imperfect forms of the $4^{\text {th }}$ conjugation were not audie-bam (as would be expected if the base form was *audiens-bam), but audī-bam. However, audī-bam could be a more recent formation than audie-bam and could first have been remodelled in the vernacular by analogy with amā-re:amā-bam, dele-re:dele-bam. ${ }^{10}$ Furthermore, there is still no satisfactory

10 The forms of the imperfect of the $4^{\text {th }}$ conjugation in $-\bar{l}$ bam appear throughout Latin literature, in archaic period mainly and in classical period only with poets (as an archaism and a metric aid), while prose writers avoid it. There is no irrefutable evidence as to which forms are older, as there is no form in - $-\vec{b} b a m$ or $i \bar{e}$ bam. A possible explanation is that forms in $-\bar{i}$ bam appeared by an analogy because, in conjugations with the base containing a long vowel $\left(1^{\text {st }}, 2^{\text {nd }}\right.$ and $\left.4^{\text {th }}\right)$, the language saw a certain whole in comparison with the $3^{\text {rd }}$ conjugation, which was left out by this analogy; in this case, the forms in -ibam are probably younger. On the basis of the repetition of forms in Old Latin, we cannot determine which form is older; forms in -ibam or -iêbam appear side by side, and there are too few prose works preserved for comparison. 
explanation why the imperfect form of the verb ire did not preserve the anticipated form *ie-bam "I went" (from *iens-bam), but was replaced by a new formation $\bar{i}$-bam, while the form audie-bam was preserved side by side with audi-bam. ${ }^{11}$

The expected phonological development also throws doubts on the derivation of legē-bam from *legens-bam. According to phonological laws, the cluster -nsf-could not develop into $-b$-, which is characteristic of the imperfect. Expected development 1 :

${ }^{*}-n s f-{ }^{*}-n f f-$

The only answer would be that $n$ before $s$ disappeared early and that $-s f$-changed into $-f$ - via $-f f$ - (e.g.. difficilis from *dis-facilis), and further into - $b$-. Expected development 2:

${ }^{*}-n s f->*_{-s f-}>*_{-f f-}>*_{-f-}>-b-12$

Although generally accepted, Stowasser and Skutsch's hypothesis did not hold water, so the search for a living Latin verb form which could serve as the base for the derivation of the imperfect continued. One such verb was pointed out by Löwe, who saw in the stem of the German weak preterite ( $(s a l b \bar{o}-d a)$ some shortened infinitive composed with the verb "to do", and incidentally remarked that this was probably the way the Italic imperfect had been formed. ${ }^{13}$ According to him, imperfect forms originated with mechanical clipping, which is how *amare-bam turned into am $\bar{a}$-bam. Yet, the theory does not hold in the $3^{\text {rd }}$ conjugation, as it fails to explain how the form *legéré-bam turned into lege-bam. In the $3^{\text {rd }}$ conjugation, Lindsay anticipated the working of an analogy (Lindsay 1897: 563-565). Am $\bar{a}$, vidé-, fini- can be treated as pure verb stems, which does not hold true for lege-, because originally, its verb stem was légé-. By analogy, verbs of the $3^{\text {rd }}$ conjugation thus probably followed verbs of the $2^{\text {nd }}$ conjugation; the origin of the form lege-bam could have followed the example of vide-bam with the analogous transfer of the long vowel. In verbs of the $4^{\text {th }}$ conjugation, such change in the formation of the imperfect probably occurred in the $2^{\text {nd }}$ century BC.

Hoffmann took an infinitive originating in the locative of a verbal noun as the starting point for his theory (Hoffmann 1920/24, 222). Thus the infinitives parä-re, legĕ-re originate in *parā-se, *legě-se and these two forms (presumably) in * parā-si, ${ }^{*}$ legé-si respectively. Since the infinitive is the locative by origin, we can presume its original locative meaning, if linking the infinitive with the past form *-fam ${ }^{14}$. This would mean that the Latin imperfective past was described:

*parāsi-fām "I was at preparing" = I was preparing

*legěsi-fām "I was at reading" = I was reading.

11 Sommer assumed that ${ }^{*} i \bar{e}$-bam in the paradigm of the verb $\bar{i}$-re remained somehow isolated and had, compared with the new formation $\bar{i}$-bam, less power than audie-bam (Sommer 1914: 144).

12

Cf. Güntert 1917: 7.

13

Cf. Hoffmann 1920/1924: 227.

14 Cf. Brugmann 1897/1916²: II $3^{2} 905$. 
Expected phonetic development:

a) The intervocalic voiceless $-f$ - in *parāsi-fām, *legési-fām would first turn into voiced -b-: " parāsi-bam, ${ }^{*}$ legési-bam.

b) As unaccented middle syllables often disappeared in prehistoric times ${ }^{15}$, we can predict the vowel to fall out:

${ }^{*}$ parāsi-bam > parās-bam

*legěsi-bam > ${ }^{*}$ legès-bam

c) In these forms, $-s$ - disappeared before voiced $-b$-, while the preceding vowel lengthened:

*parās-bam > parā-bam

${ }^{*}$ legès-bam > legē-bam (e as substitutive lengthening). ${ }^{16}$

Mayer also agrees with Hoffmann's argumentation (Mayer 1956).

Sommer, too, sees in age-bam, like in compounds of the type caleffaciō, an infinitive formation, and points out the parallel with the Slavonic imperfect * nesé-ach neso, which has been explained with the fusion of such infinitive with *es-o-m "I was": "nese-e-erom "I was at carrying" the same as age--bam "I was at leading" (Sommer 1948: 521).

The explanation for the stem of the verbs of the $3^{\text {rd }}$ and $4^{\text {th }}$ conjugations was also sought in adverbs $\bar{\imath}$-licet, vidé-licet, sci-licet, in verbs of the type cale-facio and in impersonal verbs. Adverbs $\bar{i}$-licet, vidê-licet, sci-licet are undoubtedly compounds with infinitives (ìre, vidère and scīre). The question arises about the occurrence of fusion. Presumably, it is younger than the imperfect forms $\bar{i}$-bam, vidé-bam and it cannot be said with certainty whether the infinitive forms were still *ise, *vidēse, *scise, or already ìre, vid re, *scire. Expected development:

a) the short $\check{e}$ in compounds disappears

b) $s$ (or $r$ ) assimilates into $l$

c) $-l l$ - after a long vowel changes into $-l$.

\begin{tabular}{|c|c|c|c|c|c|c|}
\hline *ise-licet & $>$ & ${ }^{*} \bar{l} s$-licet & $>$ & ${ }^{*} \bar{l}$ l-licet & $>$ & ilicet \\
\hline${ }^{*} \overline{\text { lre-licet }}$ & $>$ & ${ }^{*} \bar{l}$-licet & $>$ & ${ }^{*} \bar{l} l$-licet & $>$ & $\bar{l}$-licet \\
\hline *vidēse-licet & $>$ & *vidēs-licet & $>$ & *vidēl-licet & $>$ & vidé-licet \\
\hline *vidēre-licet & $>$ & *vidēr-licet & $>$ & *vidēl-licet & $>$ & vidè-licet \\
\hline${ }^{*}$ scīse-licet & $>$ & ${ }^{*}$ scìs-licet & $>$ & ${ }^{*}$ scìll-licet & $>$ & sci-licet \\
\hline${ }^{*}$ scīre-licet & $>$ & ${ }^{*}$ scīr-licet & $>$ & ${ }^{*}$ scìl-licet & $>$ & sci-licet \\
\hline
\end{tabular}

According to this pattern, the fusion of the infinitive and the auxiliary into the imperfect form would also be possible (Lindsay 1897: 563-565, Hoffmann 1920/1924: 229-230, LHS 19775: 566).

15 E.g. *hosti-pot(i)s > hospes; *săcro-dhö-t-s > sacerdos; *opi-ficina > officina.

16 Replacement of $-s$, which disappeared before a voiced consonant, by lengthening the previous vowel can also be found in historic times, e.g. cömis < Old Latin cosmis (Duenos), dūmus < Old Latin dusmos (Liv. Andr. trag. 39 dusmo in loco) 
Hoffmann ${ }^{17}$ anticipates a similar process with verbs of the type cale-facio, which are mostly bound to the $2^{\text {nd }}$ conjugation by their origin (Hoffmann 1920/1924: 230-231). They probably developed from the connection of the infinitive + facio: calè-facio < *alèse-facio like vidé-licet from *vidèse licet. A partial confirmation of such a supposition can be found in Old Latin, where we can find the connection of the verb facio with $\mathrm{AcI}^{18}$, e.g.

Lucil. 1270 purpureamque uvam facit albam pampinum habere

Varro rust. 3, 5, 3 quod earum aspectus ac desiderium marcescere facit volucres inclusas Phonologically, too, calē-facio can be derived from *calese-facio without any major problems. Expected development:

a) the vowel in the unaccented mid-syllable position disappears

b) $-s$ - assimilates into $-f$ -

c) $-f f$ - after a long vowel changes into $-f$ -

*calèse-facio $>{ }^{*}$ calès-facio $>{ }^{*}$ caléfffacio > calé-facio

The latter statement triggers the questions of the appearance of these forms

a) in tmesis, e.g. Cato agr. 157, 9 ferve e bene facito (as opposed to forms with no tmesis ${ }^{19}$ ); Varro rust. 1, 9, 2 perferve ita fit; 2, 9, 13 consue quoque faciunt; $3,4,1$ excande me fecerunt

or

b) in poetic licence, e.g. Lucr. 6, 962 principio terram sol excoquit et facit āre. These examples are supposed to indicate that the form lege $\bar{e}$ - was obviously some sort of a locative verbal noun analogous to the infinitive, which never appeared independently as such. Based on verbs of the type cale-facio it could be inferred that these infinitive formations (if this is what they are) were preserved until Classical Latin.

A similar development is predicted for imperfect forms which are an older category than verbs of the type cale-facio:

${ }^{*}$ calēse-fam > *alēse-bam > *alēs-bam > calé-bam.

The relationship between calē- in calē-facio and calē- in the imperfect calē-bam remains a matter for discussion. If there had been a connection between them, it would have to be preserved through the history of the language. So, even after the appearance of the imperfect ( ${ }^{*}$ cale-fām, ${ }^{*}$ sanā-fäm), the forms cale, sanā should have remained independent infinitives, but were not preserved in the language at all.

The hypothesis that the stem part with $-\bar{e}$ - originates in impersonal verbs of the $2^{\text {nd }}$ conjugation as a verbal noun with $-\bar{e}$ - (e.g. * taede bat "there was disgust" = "it was disgusting"), has not been widely accepted. ${ }^{20}$

17 Hoffmann 1920/1924: 230-231.

18 Cf. Schmalz 1928: 426.

19 Cato agr. 122, 1 in duobus congiis vini veteris in vase aheneo vel in plumbeo defervefacito; 123, 1 eam infervefacito cum congio vini veteris; 156, 6 postea fervefacito, infundito in catinum; 156, 7 infervefacito paulisper; 157, 9 postea in aulam coicito, defervefacito bene; 157,11 ubi in scutra fervefeceris. 
The last hypothesis regarding $-\bar{e}-$ is offered by Matasovic (Matasović 1997: $220-221)$ : the element $-\bar{e}$ - before the suffix $-b \bar{a}$ - in the verbs of the $3^{\text {rd }}$ and $4^{\text {th }}$ conjugations might have originated in IE suffix $-e h_{I^{-}}$, which was used for the formation of durative verbs expressing state; namely, a similar suffix also appears in the non-terminative past tense in Slavonic languages, for example Old Church Slavonic grebēaht.

What all traditional hypotheses have in common is that they consider imperfect forms as compounds, as descriptive combinations with the auxiliary * $f a \bar{m}$ ( $<^{*} b h u a m$ ) "I was". However, none of the hypotheses presented has provided a satisfactory explanation of the origin of the imperfect. More acceptable and also more plausible answers are offered by the modern theory about the origin of the imperfect: it explains the origin of the imperfect forms with the transition of IE verb categories into Latin verb categories and with internal adjustment and organisation of these. 


\section{Bibiliography}

BOPP, F. (1833/1849): Vergleichende Grammatik des Sanskrit, Zend, Griechischen, Lateinischen, Litthauischen, Gothischen und Deutschen. Berlin.

BRUGMANN, K. (1897/19162): Grundriß der vergleichenden Grammatik der idg. Sprachen. Straßburg.

BRUGMANN, K. (1922): Kurze vergleichende Grammatik der indogermanischen Sprachen. Auf Grund des fünfbändigen Grundrisses der vergleichenden Grammatik der indogermanischen Sprachen von K. Brugmann und B. Delbrück verfaßt von Karl Brugmann. Berlin \& Leipzig.

BUCK, C. D. (1904): A Grammar of Oscan and Umbrian. Boston.

ERNOUT, A.-MEILLET, A. (19743): Morphologie historique du latin. Paris.

ERNOUT, A.-MELTZER, H. (19131/19202,3): Historische Formenlehre des Lateinischen. Heidelberg.

GÜNTERT, H. (1917): Zur Herkunft und Bildung des italischen Imperfekts. Sitzungsbericht der Heidelberg. Akademie der Wissenschaft, Phil.-histor. Kl. 1917, Abhandlung 8.

HERMANN, E. (1948): Zusammengewachsene Praeteritum- und Futurum- Umschreibungen in mehreren indogermanischen Sprachzweigen. ZVS 69 (1948), 31-75.

HOFFMANN, O. (1920/1924): Latina: 2. Das Imperfektum. RM 73 (1920, 1924), Heft 4, 222-231.

KRAHE, H. (1972): Grundzüge der vergleichenden Syntax der indogermanischen Sprachen. Hrsg. von Wolfgang Meid und Hans Schmeja. Innsbruck.

KÜHNER, R.HOLZWEISSIG, F. (19946): Ausführliche Grammatik der lateinischen Sprache. I: Elementar, Formen- und Wortlehre. Hannover.

LEUMANN, M. (1924): Die ital. $f$ - und b-Tempora. IF 42 (1924), 60-75.

LHS - LEUMANN, M.-HOFMANN, J.B.-SZANTYR, A. (19775): Lateinische Grammatik. Erster Band: Lateinische Laut- und Formenlehre. Von Manu Leumann, München.

LINDSAY, W. M. A. (1897): Die lateinische Sprache. Ihre Laute Stämme und Flexionen in sprachgeschichtlicher Darstellung. Vom Verfasser genehmigte und durchgesehene Übersetzung von Hans Nohl. Leipzig, 1897, 563-565.

MATASOVIĆ, R. (1997): Kratka poredbenopovijesna gramatika latinskog jezika. Zagreb.

MAYER, A. (1956): Das lateinische Imperfekt. Glotta 35 (1956), 120.

MEILLET, A.VENDRYES, J. (1948): Traité de grammaire comparee des langues classiques. Paris.

PALMER, L. R. (1990): Die lateinische Sprache: Grundzüge der Sprachgeschichte und der historisch-vergleichenden Grammatik. Übers. von J. Krammer. Hamburg.

PLANTA, v. P. (1892/1897): Grammatik der oskisch-umbrischen Dialekte. 2 Bde. Straßburg.

POHL, Heinz-Dieter (1986): Zur Herkunft des lateinischen Imperfekts und b-Futurums. Latein und Indogermanisch. Akten der Indogermanischen Gesellschaft. Salzburg, 23.-26. September 1986. Hrsg. von Oswald Panagl und Thomas Krisch. Salzburg.

SAFAREWICZ, J. (1969): Historische lateinische Grammatik. Halle (Salle).

SCHMALZ, J. H. (1928): Lateinische Syntax und Stilistik. Neubearbeitet von J. B. Hofmann (Handbuch der klassichen Altertumswissenschaft). München.

SCHMIDT, J. (1871): Zur Geschichte des idg. Vocalismus. Weimar.

SIHLER, A. L. (1995): New Comparative Grammar of Greek and Latin. New York-Oxford.

SKUTSCH, F. (1914): Kleine Schriften. Leipzig, 1914.

SOMMER, F. (1914): Kritische Erläuterungen zur lateinischen Laut- und Formenlehre. Heidelberg.

SOMMER, F. (1948): Handbuch der lateinischen Laut- und Formenlehre. Heidelberg.

SOMMERFELT, A. (1907): Le futur Irlandais en -f. MSL 22 (1907), 230-233.

SZEMERÉNYI, O. (19904): Einführung in die vergleichende Sprachwissenschaft. Darmstadt.

STOWASSER, J. M.: Zeitschrift für das österreichische Gymnasium. 52 (1901), 195 ss.

THURNEYSEN, R. (1909): Handbuch des Alt-irischen. Heidelberg.

WALDE, A. (1917): Über älteste sprachliche Beziehungen zwischen Kelten und Italikern. Rektoratsschrift. Innsbruck, 1917.

WALDE, A.-HOFMANN, J. B.: Lateinisches etymologisches Wörterbuch. Heidelberg 1938-1954³. 
Povzetek

\section{TRADICIONALNA TEORIJA O NASTANKU LATINSKEGA IMPERFEKTA}

Latinski imperfekt, tvorjen s pripono - $b a-$, ki jo v imperfektu vsebujejo vsi latinski glagoli razen esse, funkcionalno ustreza indoevropskemu imperfektu in nadaljuje njegov imperfektivni glagolski vid, formalno pa je brez sleherne povezave $z$ njim. Pripona - $b a$ - je po svojem izvoru preteritalna oblika pomožnega glagola "biti" in izhaja iz *bhūa $m$ (< iz ie. baze *bheunH-), ki je v (pra)italskem jeziku prešel v *fam (prim. oskiško obliko fufans = lat. erant) oz. -bam. Imperfekt obravnavamo skupaj s futurom ( $b$ - oz. $f$-časi); medtem ko $b$-futur razen $\mathrm{v}$ italskih jezikih (v latinščini in faliskiškem narečju) najdemo tudi v keltščini, pa $b$ - (oz. $f$-) imperfekt najdemo samo v italskih jezikih: v latinščini ter oskiškem in umbrijskem narečju. Glede kronologije nastanka obeh časov ni enotnega mnenja; zanesljivih dokazov ali oblik, ki bi potrjevale, kateri od obeh časov se je izoblikoval prej, ni.

Tradicionalna teorija o nastanku latinskega imperfekta temelji na "teoriji zloženke" (Kompositiontheorie); nastanek imperfektovih oblik obravnava izrecno na osnovi zlaganja glagolskega debla (ali nominalne oblike) ter pripone -ba-. V 1., 2., delno 4. konjugaciji ter pri glagolih dare, ìre in esse, kjer oblike imperfekta tvorimo iz prezentovega debla, ni posebnosti; v 3. in 4. konjugaciji pa je deblo nekoliko spremenjeno. Slovničarji so večkrat skušali razložiti debelni del 3. in 4. deklinacije, vendar noben pokus ni dal povsem zadovoljivega rezultata. Pričujoči članek skuša sumarno predstaviti rezultate teh poskusov, njihove prednosti in slabosti. 